\section{Acknowledgments}

I wish to thank Martin Gerard for his encouragement, Andy Didiuk for comments on the species of salamander present in our area, and Stuart Houston for assistance in preparing this report.

1. Conant, R. 1958. A Field Guide to Reptiles and Amphibians. Houghton Mifflin, Boston.
2. Houston, C.S. 1977. Changing patterns of Corvidae on the prairies. Blue Jay 35:149-1563.

3. Nelson, A.L. 1934. Some early summer food preferences of the American Raven in southeastern Oregon. Condor 36:10-15.

\title{
THE WESTWARD SPREAD OF THE BARRED OWL
}

C. STUART HOUSTON, 863 University Drive, Saskatoon SK S7N 0J8, and KEVIN J. McGOWAN, Department of Ecology and Evolutionary Biology, Corson Hall, Cornell University, Ithaca NY 14853-2701.

Only during this century did the Barred Owl spread westward from Manitoba. Except for a widely-cited specimen from Calgary in 1912, now known to be an error, all other evidence has pointed to this owl being a new arrival. The alternative possibility, based on the Calgary specimen, was that the Barred Owl might have been present earlier in Saskatchewan and Alberta, but so rare and with so few observers, that it was overlooked. We argue that it is a new arrival, certainly in Alberta, British Columbia, and the northwestern states, and perhaps in Saskatchewan as well. Either it was overlooked in Saskatchewan for some years or its thin colonization of Saskatchewan and Alberta was nearly simultaneous.

In the eastern United States, west to the Red River valley on the western margin of Minnesota, Barred Owls are resident primarily in oak forests, but also in old-growth stands of maple and hemlock. Large, old trees offer suitable cavities for their nesting. ${ }^{10}$

It appears that Barred Owls followed the wooded Red and Assiniboine river valleys in their first incursion into Manitoba. Until the late 1880s, Barred Owls were considered "rare" at Winnipeg and adjacent southeastern Manitoba (three records) and "very rare, one specimen" slightly farther west at Portage la Prairie. ${ }^{21}$ Later at Winnipeg, there was a sight record for 1901, four specimens were taken in 1906 and one in 1908. ${ }^{16}$ A second specimen from Portage la Prairie was taken in May 1899. ${ }^{16}$ The range was extended westward when a specimen was taken in old-growth forest at Riding Mountain in January 1905. ${ }^{16}$ Taverner (1936) was unequivocal as to its 
distribution: "In Canada, west to, and including, southern Manitoba."19 Two specimens were collected at The Pas, Manitoba, close to the Saskatchewan boundary, by Sam Waller on 15 September and 11 October 1946 (his first in 16 years of residence at Lake St. Martin and The Pas). ${ }^{5}$

In Saskatchewan, none was seen by J. Dewey Soper, who studied the birds of Prince Albert National Park intermittently, 1940-1946; by T.E. Randall, who did the same at Kazan Lake, June to October 1942; by E. Derek Beacham who recorded 197 species while living at Prince Albert for 26 months, 1968-1970, and by resident ornithologist Maurice Street at Nipawin, who died in 1966. All four worked wholly (Soper and Randall) or in part in mixed forest, much of it old-growth, and Street, in his time, was renowned for his ability to identify birds by sound.

The spread of the Barred Owl into Saskatchewan may have occurred first along the riparian forest of the Saskatchewan River west from The Pas, Manitoba. The first Saskatchewan specimens were taken by Russell Robertson near Cumberland House in March 1948 and again on 2 June 1959, the latter his second sighting in 11 years. ${ }^{7}$ The remaining spread westward has been in a narrow band along the southern margin of the mixed forest. The next sighting was by Steve and Anton Waycheshen near High Hill, northeast of Kelvington, in December 1958; they found the first Saskatchewan nest at the top of a black poplar stub on 4 June $1961 .{ }^{6}$ Subsequent nest records and summer sightings extend across the southern mixed forest, including the Carrot River and Saskatchewan River lowlands, and Duck Mountain and Greenwater Provincial Parks, many in the vicinity of lakes, including Emma Lake and Flotten Lake. In 1994 through 1996,
Mazur found 15 Barred Owl nests, east of Prince Albert National Park, while doing a M. Sc. study of this species; this owl requires tree cavities in old-growth, mixedwood forest for nest sites. ${ }^{12}$ Smith mapped 41 Saskatchewan locations and speculated that fire control had "allowed the establishment of the old-growth forest it requires." Smith perceptively noted the correlation between Barred Owl range and stands of White Spruce with aboveaverage productivity, demonstrated by an annual growth rate greater than $1.1 \mathrm{~m}^{3}$ of wood per hectare. ${ }^{18}$

After investigation, we submit that the first two published records for Alberta should be disregarded. One of us (KJMcG) reviewed the "unverified" 1912 specimen, 2,13,14 collected thirty years in advance of any other Alberta or Saskatchewan record. Although the current tag for CU4295, Strix varia [Barred Owl], male, in the Cornell University Museum of Vertebrates, gives the collection date as 18 February 1912, and the location as "Canada, Alberta, Calgary," this is not the original

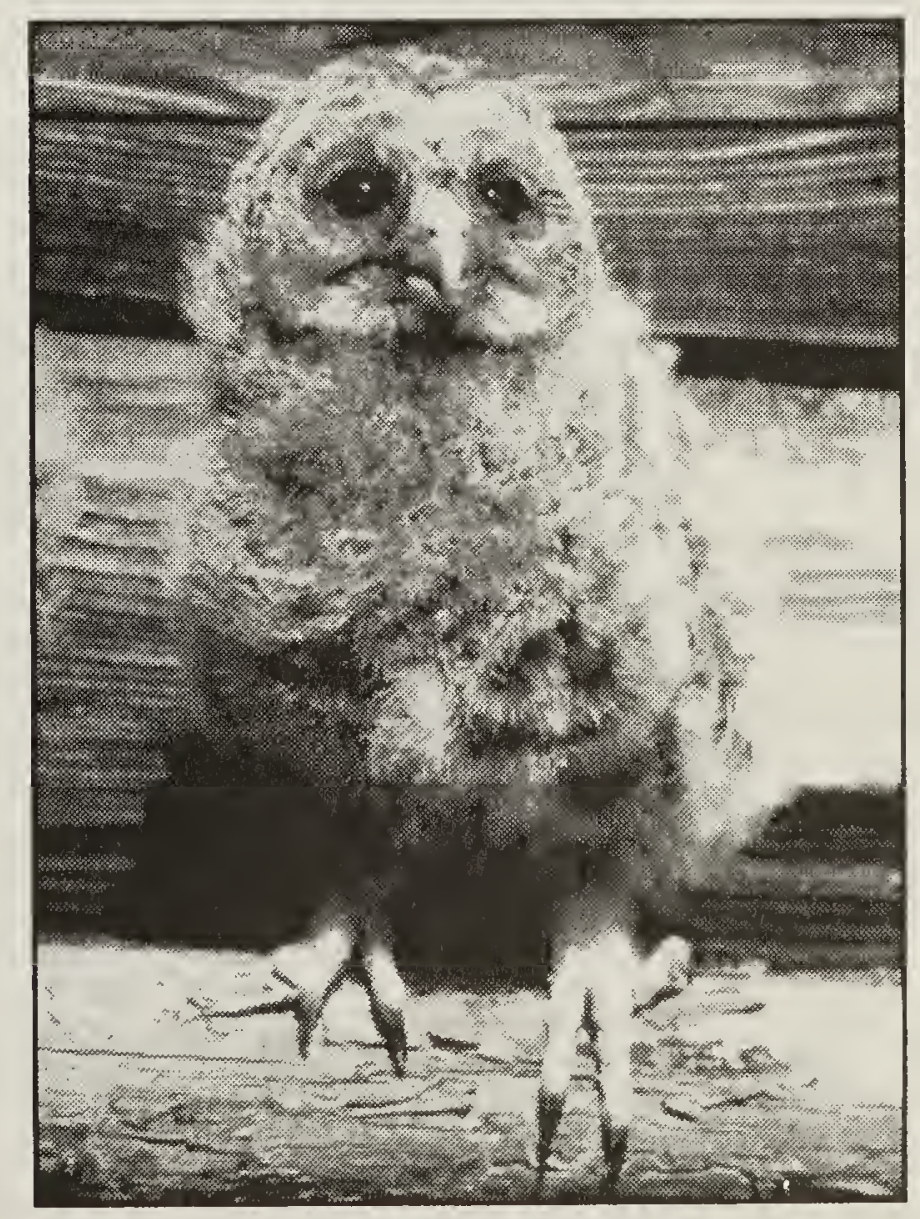

Nestling Barred Owl 


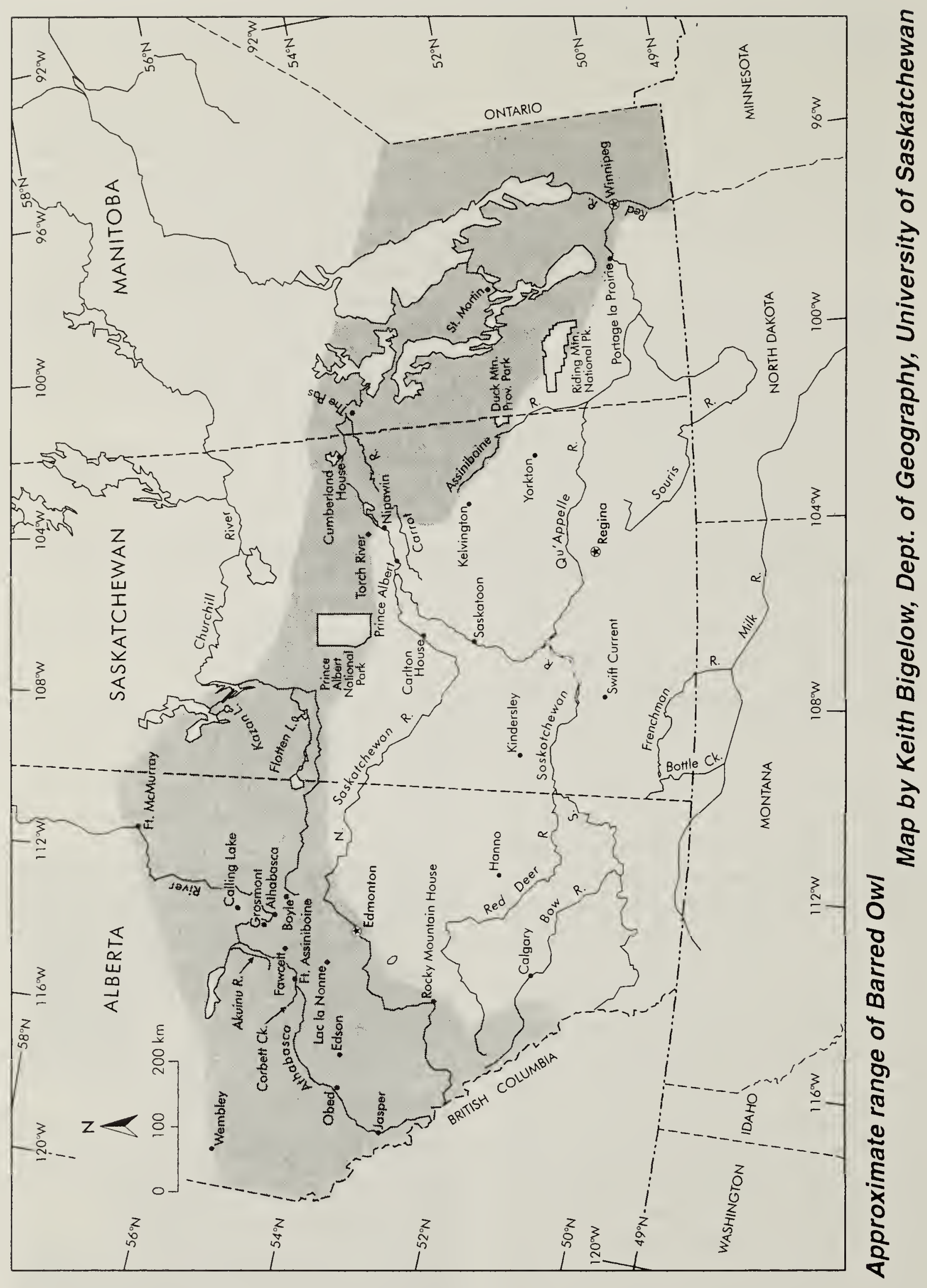


collector's label, and the name of the collector is not available. The specimen came from the collection of Frank $S$. Wright of Auburn, New York, who traded for specimens from all over the world. A careful review of Wright's accompanying catalogue shows that specimen 353 was a Barred Owl from Skaneateles, New York, October 21, 1911, and 354 was a Richardson's [Boreal] Owl from Calgary, Alberta, February 18, 1912. Wright renumbered his collection several times, and in a 1919 revision the Boreal Owl specimen following the Skaneateles Barred Owl in his catalogue became a Barred Owl from Calgary. The transcription error was maintained in later versions of the catalogue, and the wrong locality and date were thereby assigned to a Barred Owl specimen. (At present, both the Boreal and Barred owl specimens are labeled from Calgary in 1912.)

A brief sighting by Gus Crossa of a Barred Owl seen only in flight at Pigeon Lake on 28 May 1913, should also be disregarded. Crossa made at least two other misidentifications in the same report (Black-throated or Arctic Loon and the Field Sparrow) ${ }^{4}$

Although Edward Preble believed he heard a Barred Owl near Fort McMurray, Alberta in May 1934, substantive Alberta reports began in 1945. The first unequivocal Alberta record was a specimen collected at Kvass Creek, about $130 \mathrm{~km}$ northwest of Jasper, on 9 August 1945. Next came a sighting at Wembley in the autumn of 1952; a feather from Corbett Creek, 11 May 1953; a specimen from Calling Lake, 18 December 1953; a specimen shot at Grosmont, 27 March 1954; one photographed along Akuinu Creek, northwest of Flatbush, 11 April 1954; and two caught in weasel traps in early 1954 at Obed Lake. ${ }^{14}$ Oeming added six additional records: a pair of skins from east of Fawcett, March 1954; a specimen taken from below a Great Gray Owl nest west of Rocky Mountain House on 15 May 1954; one caught in a weasel trap at Goose Lake, west of Fort Assiniboine, February 1955; one caught in a trap at Obed Lake, April 1955; one observed at Corbett Creek, 18 May 1955; one heard near Edson, 20 May 1955. ${ }^{11,13}$ The last three records were the beginning of a switch from its usual mixed-wood habitat across Saskatchewan and most of Alberta, and instead an adaptation to upper foothill and Rocky Muuntain forests "of predominantly coniferous character."' Edgar Jones banded three young at a nest in a dead poplar in Edmonton on 28 May 1966, and found a nest with three eggs nearby on 15 April 1966, the first authentic Alberta nests, ${ }^{11}$ though fledged young had been seen at Prairie River, south of High Prairie, on 11 July $1949 .^{2}$

Could the Barred Owl, with its distinctive call, have been present but overlooked in mixed forest areas until 1940 ? We believe the answer is a resounding NO! One of Canada's most indefatigable owl searchers, Archibald D. Henderson, lived in and explored thoroughly the ideal mixed forest and muskeg habitat at the north edge of Lac la Nonne, from 1919 through 1954. As proof of his nest finding skills, and his hikes into woods long before the snow had melted, he found far more Great Gray Owl nests (14) than anyone else in North America. He had Goldeneye duck boxes, suitable for Barred Owl use, in place from 1920 onwards. He was visited by at least fourteen prominent oologists and ornithologists, who also searched his area and that farther north along the Athabasca River. ${ }^{9}$ Similarly, T.E. Randall lived in excellent mixed forest habitat at Athabasca and at Boyle from April 1928 through April 1936. As a measure of his late-winter diligence, 
Randall found 43 Gray Jay nests in 1930 alone. ${ }^{8}$ Neither Henderson nor Randall reported a Barred Owl.

Finally, weasel and muskrat traps were present through the southern fringe of mixed forest, operated by professional full-time trappers, as well as farmers and farm lads. No Barred Owls were reported in traps in Alberta until 1954 and 1955. They were still uncommon and second rarest of eleven owl species, in 1982-1985, when Boxall compiled information on owls caught in such traps and mounted by taxidermists. Boxall classed the Barred Owl as "one of the rarest owls in the province despite its large size and characteristic vocal behavior." There were only eight Barred Owl breeding records for Alberta through 1980.2 Semenchuk's Atlas by our count shows another 12 probable and 20 possible breeding localities and 9 sightings of individual birds. ${ }^{15}$

That the Barred Owl spread westward from Alberta into British Columbia and then, secondarily, south into the northwestern states, is undisputed. It "was just beginning to expand its range into British Columbia about ... 1947."3 The first two B.C. records were a specimen from Liard Crossing in 1943 and a nest at Hazeltine Creek in the southern Nechako Lowlands in April 1946. Its subsequent spread as a new breeding species within the boreal forest southward and westward over the next 30 years, and then into Washington, Idaho, extreme western Montana and finally Oregon, has been well described.3, 17, 20 As Taylor and Forsman comment, it is unlikely that the species could have been present earlier, and gone undetected. ${ }^{20}$ We submit that, based on negative evidence from Henderson, Randall and trapping, that this statement applies equally to Alberta, and perhaps to Saskatchewan as well.

\section{Acknowledgments}

We wish to thank Kurt Mazur and J. Frank Roy for constructive criticism of an earlier draft. Eric and $\mathrm{Al}$ Oeming kindly provided relevant pages from the 1955 thesis. Diane Roddy of Weyerhauser provided clarification concerning White Spruce growth rates per hectare.

1. Boxall, P.C. 1986. Additional observations of the Barred Owl in Alberta. Blue Jay 44:41-43.

2. Boxall, P.C. and P.H.R. Stepney. 1984. The distribution and status of the Barred Owl in Alberta. Can. Field-Nat. 96:46-50.

3. Campbell, R.W., N.K. Dawe, I. Mactaggart-Cowan, J.M. Cooper, G.W. Kaiser and M.C.E. McNall. 1990. The Birds of British Columbia. Royal British Columbian Museum and Canadian Wildlife Service, Victoria, B.C. Vol. 2:374-375.

4. Crossa, G. 1914. Notes from Alberta, Canada. Oologist 31:54-56.

5. Houston, C.S. 1959. First records of the Barred Owl in Saskatchewan. Blue Jay 17:94.

6. Houston, C.S. 1961. First Saskatchewan nest of Barred Owl. Blue Jay 19:114.

7. Houston, C.S., and M.G. Street. 1959. The birds of the Saskatchewan River, Carlton to Cumberland. Saskatchewan Natural History Soc. Spec. Publ. 2.

8. Houston, C.S., M.J. Bechard, and P.H.R. Stepney. 1984. Thomas Edmund Randall, nest-finder supreme. Blue Jay 42:226-232.

9. Houston, C.S. and M.J. Bechard. 1990. A.D. Henderson, Alberta's 
foremost oologist, 1878-1963. Blue Jay 48:85-96.

10. Johnsgard, P.A. 1988. North American owls. Smithsonian Institution Press, Washington.

11. Jones, E.T. 1987. Early observations of the Barred Owl in Alberta. Blue Jay 45:31-32.

12. Mazur, K.M., P.C. James, and S.D. Frith. 1997. Barred Owl (Strix varia) nest site characteristics in the boreal forest of Saskatchewan, Canada. Pp. 267-271 In: J.R. Duncan, D.H. Johnson, and T.H. Nichols, eds., Biology and conservation of owls of the northern hemisphere. USDA Forest Service, Gen. Tech. Rpt. NC-190.

13. Oeming, A.F. 1955. A preliminary study of the Great Gray Owl, Scotiaptex nebulosa nebulosa, with observations on some other species of owls. M.Sc. Thesis, University of Alberta.

14. Oeming, A.F., and E.T. Jones. 1955. The Barred Owl in Alberta. Can. FieldNat. 69:66-67.
15. Semenchuk, G.P. 1992. The atlas of breeding birds of Alberta. Federation of Alberta Naturalists, Edmonton.

16. Seton, E.T. 1908. Recent bird records for Manitoba. Auk 25:450-454.

17. Shea, D.S. 1974. Barred Owl records in western Montana. Condor 76:222.

18. Smith, A.R. 1996. Atlas of Saskatchewan birds. Saskatchewan Natural History Society Special Publication \#22.

19. Taverner, P.A. 1940. Birds of Canada. Musson, Toronto.

20. Taylor, A.S. Jr., and E.D. Forsman. 1976. Recent range extensions of the Barred Owl in western North America, including the first records for Oregon. Condor 78:560-561.

21. Thompson [-Seton], E.E. 1890.

The birds of Manitoba. Proc. U.S. Nat. Mus. 13:457-643.

"The wormlike, bristled tongues of flower bats rival hummingbird and honeyeater tongues in length, but these mammals have one trick that is absent in most nectar birds. Most bats eat and digest pollen. Their snouts and "chins" wear branched hairs and whiskers that gather grains as the animals bump into anthers. Their muscular tongues lick the caked pollen from their muzzles."

Peter Bernhardt, The Rose's Kiss 